\title{
Solution Structures of a DNA Dodecamer Duplex with and without a Cisplatin 1,2-d(GG) Intrastrand Cross-Link: Comparison with the Same DNA Duplex Containing an Oxaliplatin 1,2-d(GG) Intrastrand Cross-Link†,,‡
}

\author{
Yibing Wu§, Debadeep Bhattacharyya§, Candice L. King§, Irene Baskerville-Abraham", \\ Sung-Ho Huh ${ }^{\perp}$, Gunnar Boysen $\|$, James A. Swenberg\|, Brenda Temple ${ }^{\perp}$, Sharon L. \\ Campbell ${ }^{*}, \S, \perp$, and Stephen G. Chaney ${ }^{*}, \S, \perp$ \\ $\S$ Department of Biochemistry and Biophysics, School of Medicine, University of North Carolina, \\ Chapel Hill, North Carolina 27599-7260 \\ "Department of Environmental Sciences and Engineering, School of Public Health, University of \\ North Carolina, Chapel Hill, North Carolina 27599 \\ ${ }^{\perp}$ Lineberger Comprehensive Cancer Center, University of North Carolina, Chapel Hill, North \\ Carolina 27599
}

\section{Abstract}

\begin{abstract}
Proteins that discriminate between cisplatin-DNA adducts and oxaliplatin-DNA adducts are thought to be responsible for the differences in tumor range, toxicity, and mutagenicity of these two important chemotherapeutic agents. However, the structural basis for differential protein recognition of these adducts has not been determined and could be important for the design of more effective platinum anticancer agents. We have determined high-resolution NMR structures for cisplatin-GG and undamaged DNA dodecamers in the AGGC sequence context and have compared these structures with the oxaliplatin-GG structure in the same sequence context determined previously in our laboratory. This structural study allows the first direct comparison of cisplatin-GG DNA and oxaliplatin-GG DNA solution structures referenced to undamaged DNA in the same sequence context. Non-hydrogen atom rmsds of 0.81 and 1.21 were determined for the 15 lowest-energy structures for cisplatin-GG DNA and undamaged DNA, respectively, indicating good structural convergence. The theoretical NOESY spectra obtained by back-calculation from the final average structures showed excellent agreement with the experimental data, indicating that the final structures are consistent with the NMR data. Several significant conformational differences were observed between the cisplatin-GG adduct and the oxaliplatin-GG adduct, including buckle at the $5^{\prime} \underline{\mathrm{G}} 6{ }^{\circ} \mathrm{C} 19$ base pair, opening at the $3^{\prime} \underline{\mathrm{G}} 7 \cdot \mathrm{C} 18$ base pair, twist at the A5 6 6 $\bullet$ T20C19 base pair step, slide, twist, and roll at the $\underline{\mathrm{G}} 6 \underline{\mathrm{G}} 7 \cdot \mathrm{C} 19 \mathrm{C} 18$ base pair step, slide at the $\underline{\mathrm{G}} 7 \mathrm{C} 8 \cdot \mathrm{C} 18 \mathrm{G} 17$ base pair step, $\underline{\mathrm{G}} 6 \mathrm{G} 7$ dihedral angle, and overall bend angle. We hypothesize that these conformational differences may be related to the ability of various DNA repair proteins, DNA binding proteins, and DNA polymerases to discriminate between cisplatin-GG and oxaliplatin-GG adducts.
\end{abstract}

\footnotetext{
${ }^{\dagger}$ This work was supported by NIH Grant CA8440 (to S.G.C.) and NIEHS Grant P30ES10126 (to J.A.S.).

\$Coordinates are available from the Protein Data Bank (PDB): 2NPW for the averaged structure of the CP-GG adduct and 2NQ0 for the family of the 15 best structures, 2NQ1 for the averaged structure of undamaged DNA in the AGGC sequence context, and 2NQ4 for the family of the 15 best structures.

* To whom correspondence should be addressed: Department of Biochemistry and Biophysics, School of Medicine, University of North Carolina, Chapel Hill, NC 27599-7260. Telephone: (919) 966-3286. E-mail: stephen_chaney@med.unc.edu or cambesl@med.unc.edu..
} 
Cisplatin [CP, cis-diamminedichloroplatinum(II)] and carboplatin [CBDCA, cisdiammine-1,1-cyclobutanedicarboxylatoplatinum(II)] are widely used for treatment of testicular cancer, ovarian cancer, head and neck tumors, and a variety of other solid tumors. However, many tumors are intrinsically resistant or develop acquired resistance to these chemotherapeutic agents, and tumors that are resistant to one of these platinum compounds are usually cross-resistant to the other. The mutagenicity of $\mathrm{CP}$ in vivo (1) is also of concern because secondary malignancies have been associated with CP chemotherapy (2).

Considerable effort has been spent to develop third-generation platinum anticancer agents that would not share these limitations. Oxaliplatin [OX, $\operatorname{trans}-(R, R)-1,2-$

diaminocyclohexaneoxalatoplatinum(II)] is one such compound and has recently been approved for the treatment of colorectal cancer and tumors that are resistant to $\mathrm{CP}$ and CBDCA. While OX does exhibit some mutagenicity (3), it appears to be less mutagenic than CP (4). CP and CBDCA form Pt-DNA adducts that contain the cis-diammine carrier ligands, while OX forms Pt-DNA adducts that contain the trans- $(R, R)-1,2-$ diaminocyclohexane carrier ligand. For the sake of simplicity, we will refer to these as $\mathrm{CP}-$ DNA and OX-DNA adducts, respectively, throughout this work. Other than the differences in carrier ligand, the adducts formed by CP, CBDCA, and OX appear to be identical in terms of the type of adduct formed (60-65\% intrastrand GG, 25-30\% intrastrand AG, 5-10\% intrastrand GNG, and 1-3\% interstrand) and the site of adduct formation (5-7).

Because of their abundance, the intrastrand GG adducts are thought to be major determinants of the cytotoxic response to platinum anticancer agents. The basis for the differences in tumor range and mutagenicity of OX compared to CP and CBDCA is not known but is thought to be determined by the ability of proteins involved in damage recognition, damage repair, and/or damage tolerance to discriminate between $\mathrm{CP}$ and $\mathrm{OX}$ adducts. For example, hMSH2 and MutS bind with greater affinity to $\mathrm{CP}-\mathrm{GG}$ adducts than to $\mathrm{OX}-\mathrm{GG}$ adducts $(8,9)$, and as might be expected from this difference in binding affinity, defects in mismatch repair result in resistance to CP and CBDCA, but not to OX $(8,10-13)$. Similarly, a number of damage recognition proteins and transcription factors, especially those with HMG domains, have been shown to discriminate between $\mathrm{CP}-$ and $\mathrm{OX}-\mathrm{GG}$ adducts $(14,15)$. The mechanism(s) by which the binding of these proteins to Pt-DNA adducts influences the cytotoxic response is not known but has been postulated to involve shielding of the adducts from DNA repair and tolerance mechanisms (16-19), activation of signaling pathways leading to cell cycle arrest or apoptosis, and/or hijacking of transcription factors needed for DNA replication or cell division $(15,20)$. The binding specificity has been determined for only a few of these proteins, but where it has been studied, these proteins bind to CP-GG adducts with higher affinity than to OX-GG adducts $(14,15,21)$. Finally, translesion DNA polymerases such as pol $\beta$ and pol $\eta$ have been shown to bypass OX-GG adducts with higher efficiency than CP-GG adducts $(19,22,23)$, which might contribute to the differences in $\mathrm{CP}$ and $\mathrm{OX}$ mutagenicity.

The $\mathrm{CP}-$ and $\mathrm{OX}-\mathrm{GG}$ adducts form in the major groove and have been shown to bend the DNA in the direction of the major groove (24-28). The proteins that discriminate between $\mathrm{CP}-$ and $\mathrm{OX}-\mathrm{GG}$ adducts either bind to bent DNA or bend the DNA in the direction of the major groove after binding (29-32). Because these proteins primarily interact with the minor groove, we have hypothesized that the ability of the proteins to discriminate between CPand $\mathrm{OX}-\mathrm{GG}$ adducts probably results from subtle differences in conformation or conformational dynamics in the DNA containing the two adducts rather than from physical interaction of the proteins with the carrier ligands of the adducts in the major groove (26). A number of structures have been reported for CP-GG and OX-GG adducts $(24,25,27,33$, 34). The overall conformation of DNA containing these adducts appears to be similar, but exact comparisons have been difficult to make because the structures have been determined 
by different techniques (crystallography vs NMR), in different sequence contexts, and with oligonucleotides that differ in length. Further, the NMR structures obtained to date have varied with respect to the number and resolution of NMR constraints obtained and the molecular mechanics simulations used to convert the NMR constraints to final structures (24-26). X-ray crystallographic structures have been reported for the CP-GG and OX-GG adducts in the TGGT sequence context $(27,28)$, but differences between the solution and Xray structures (26) of the OX-GG DNA adduct suggest that the X-ray structures may have been at least partially constrained by crystal packing restraints (26). CP-GG adducts appear to be more mutagenic in the $\mathrm{AGG}$ sequence context than in the $\underline{\mathrm{CGG}}, \mathrm{TGG}$, or GGG sequence context (35-38). In addition, our previous studies with translesion DNA polymerases have utilized DNA templates with oxaliplatin located in the AGGC sequence context $(19,22,23,39)$. Thus, we have recently obtained a high-resolution NMR solution structure of the $\mathrm{OX}-\mathrm{GG}$ adduct in the mutagenic $\mathrm{AGGC}$ sequence context (the underlined bases indicate the position of the OX-GG adduct) (26).

In this paper, we report high-resolution NMR solution structures of the CP-GG adduct and undamaged DNA in the same sequence context. Moreover, the solution structures were determined using the same experimental approach employed for the OX-GG adduct. This is the first direct comparison of the $\mathrm{CP}-\mathrm{GG}$ adduct, the $\mathrm{OX}-\mathrm{GG}$ adduct, and undamaged DNA solution structures in the same sequence context. This study has allowed us to resolve the effects of sequence context and platinum carrier ligand on several previously reported chemical shift anomalies. For example, we find that several unusual chemical shifts, previously reported for the OX-GG adduct compared to earlier NMR solution structures of $\mathrm{CP}-\mathrm{GG}$ adducts, were also seen for the $\mathrm{CP}-\mathrm{GG}$ adduct in the AGGC sequence context. Thus, these chemical shift differences appear to reflect the effect of sequence context rather than the presence of the trans-(R,R)-1,2-diaminocyclohexane carrier ligand. The direct comparison of NOESY data from the $\mathrm{CP}-\mathrm{GG}$ adduct, the $\mathrm{OX}-\mathrm{GG}$ adduct, and undamaged DNA in the same sequence context has also allowed us to more accurately determine the effect of CP-GG and OX-GG adducts on NOE cross-peak volumes of nearby DNA residues. For example, we have been able to show that the unusually weak cross-peak between $\mathrm{H} 2^{\prime}$ of the $\mathrm{C}$ complementary to the $5^{\prime} \mathrm{G}$ and $\mathrm{H} 6 / \mathrm{H} 8$ of the base complementary to the $5^{\prime}$ flanking residue reported by Marzilli et al. (25) is a feature of CP-GG adducts, but not of $\mathrm{OX}-\mathrm{GG}$ adducts. Finally, the direct comparison of $\mathrm{CP}-\mathrm{GG}$ and $\mathrm{OX}-\mathrm{GG}$ solution structures has allowed us to identify several conformational differences not seen in the crystallographic comparison of the two adducts in the TGGT sequence context. For example, significant differences were observed between the two adducts: buckle at the $5^{\prime}$ $\underline{\mathrm{G}} 6 \cdot \mathrm{C} 19$ base pair, opening at the $3^{\prime} \underline{\mathrm{G}} 7 \cdot \mathrm{C} 18$ base pair, twist at the A5 $\underline{\mathrm{G}} 6 \cdot \mathrm{T} 20 \mathrm{C} 19$ base pair step, slide, twist, and roll at the $\underline{\mathrm{G}} 6 \underline{\mathrm{G}} 7 \cdot \mathrm{C} 19 \mathrm{C} 18$ base pair step, slide at the $\underline{\mathrm{G}} 7 \mathrm{C} 8 \cdot \mathrm{C} 18 \mathrm{G} 17$ base pair step, $\underline{G} \underline{G} 7$ dihedral angle, and overall bend angle. These subtle conformational differences may allow differential recognition of $\mathrm{CP}-$ and $\mathrm{OX}-\mathrm{GG}$ adducts by critical DNA binding proteins that influence the cytotoxic response to these adducts.

\section{MATERIALS AND METHODS}

\section{Preparation and HPLC Purification of the CP-GG Oligonucleotide}

The GG strand (the strand containing the Pt-GG adduct) and complement (CC strand) were purchased from Operon Biotechnologies, Inc. The GG strand containing the cisplatin adduct was prepared using our previously described procedure (26). The DNA duplex (Figure 1) was prepared by adding the CC strand solution to the GG strand in NMR buffer [100 mM $\mathrm{NaCl}$ and $5 \mathrm{mM}$ phosphate buffer $(\mathrm{pH}$ 7.0)] at a calculated 1:1 ratio. The DNA was annealed by cooling overnight from $70{ }^{\circ} \mathrm{C}$ to room temperature. The $1: 1$ ratio of CC strand to GG strand was verified by analysis of two-dimensional (2D) DQF-COSY NMR spectra as described previously (26). 


\section{Characterization of the CP-GG Adduct by Liquid Chromatography and Mass Spectroscopy (LC-MS)}

LC-MS characterizations of the CP-GG adduct and undamaged DNA in the AGGC sequence context were performed following the procedure reported previously, with slight modifications (26). The platinated and undamaged 12-mer GG strand were first separated by HPLC. Following desalting and concentration, the purity of the CP-adducted 12-mer GG strand was confirmed by denaturing gel electrophoresis. No unplatinated 12-mer GG strand was detected by this method, indicating that the CP-adducted 12-mer GG strand was $>95 \%$ pure (data not shown). The $\mathrm{CP}[\mathrm{d}(\mathrm{GpG})]$ adduct and undamaged DNA digests were analyzed on a Surveyor LC system, connected to Surveyor photodiode array (PDA) and LCQ ${ }^{D E C A}$ ion trap mass spectrometer (Thermo Finnigan, San Jose, CA). A Clarity $3 \mu \mathrm{m}$ Oligo-RP column $(100 \mathrm{~mm} \times 4.60 \mathrm{~mm})($ Phenomenex, Torrance, $\mathrm{CA})$ was operated with a linear gradient from $100 \% 10 \mathrm{mM}$ ammonium acetate (pH 3.5) to $80 \% \mathrm{MeOH}$ in $10 \mathrm{mM}$ ammonium acetate for $20 \mathrm{~min}$ at a flow rate of $200 \mu \mathrm{L} / \mathrm{min}$. UV spectra $(\lambda=200-400 \mathrm{~nm})$ were recorded with a Finnigan Surveyor PDA detector, and positive and negative full scan $(\mathrm{m} / \mathrm{z} 80-1000)$ mass spectra were acquired with Xcalibur (Thermo Finnigan).

\section{NMR Experiments}

Two NMR samples were prepared for both the undamaged DNA and CP-GG DNA adduct, one in $5 \% \mathrm{D}_{2} \mathrm{O} / 95 \% \mathrm{H}_{2} \mathrm{O}$ buffer $\left(\mathrm{H}_{2} \mathrm{O}\right.$ sample) for detection of exchangeable protons and the other in $100 \% \mathrm{D}_{2} \mathrm{O}$ buffer $\left(\mathrm{D}_{2} \mathrm{O}\right.$ sample) for detection of nonexchangeable protons. All NMR spectra were acquired on a Varian Inova 600 or $800 \mathrm{MHz}$ spectrometer. The carrier frequency for protons was set on the $\mathrm{H}_{2} \mathrm{O}$ signal. One-dimensional (1D) proton spectra were recorded at temperatures ranging from 2 to $40{ }^{\circ} \mathrm{C}$ for detection of exchangeable protons. NOESY spectra were recorded at $800 \mathrm{MHz}$ using a mixing time of $200 \mathrm{~ms}, 32$ transients, and 320 or 400 complex FIDs corresponding to spectral widths of 20 and $9 \mathrm{ppm}$ in both dimensions for the samples in $\mathrm{H}_{2} \mathrm{O}$ and $\mathrm{D}_{2} \mathrm{O}$, respectively. WATERGATE was employed to suppress the water peak in water samples. Distance constraints were obtained from the 200 ms NOESY spectra in both $\mathrm{H}_{2} \mathrm{O}$ and $\mathrm{D}_{2} \mathrm{O}$ (40). The assignments were obtained initially from NOE connectivities and confirmed by analysis of 2D DQF-COSY (41) $(2048 \times 720$ complex points, $9 \mathrm{ppm}$ spectral width in both dimensions, 32 transients) and TOCSY data ( $2048 \times 320$ complex points, 9 ppm spectral width in both dimensions, 32 transients). 2D DQF-COSY data were also used to extract $J$ coupling constraints for determination of sugar pucker. 2D ${ }^{1} \mathrm{H}-{ }^{31} \mathrm{P}$ HETCOR (42) (heteronuclear correlation spectroscopy) data were collected for the $\mathrm{D}_{2} \mathrm{O}$ samples $(800 \times 112$ complex points, spectral width of $2040 \times 900 \mathrm{~Hz}$, 320 transients) at $600 \mathrm{MHz}$. The ${ }^{1} \mathrm{H}$ and ${ }^{31} \mathrm{P}$ chemical shifts were referenced relative to internal TSP and external $10 \%(\mathrm{w} / \mathrm{v})$ trimethyl phosphate at $0.0 \mathrm{ppm}$, respectively. NMR data were processed with NMRPipe and analyzed with Felix (version 2000; Molecular Simulations, Inc., San Diego, CA).

\section{Structure Calculations}

The structure of the DNA duplexes was calculated using CNS (Crystallographic and NMR System) version 1.1 with a simulated annealing protocol (43). To construct the CP intrastrand platinum cross-link between $\underline{\mathrm{G} 6}$ and $\underline{\mathrm{G} 7}$, two new residues (XGU and YGU) were added to the topology and parameter database of CNS. Residue YGU was modified for $\underline{\mathrm{G} 6}$ by adding a bond between the $\mathrm{N} 7$ atom of $\mathrm{G6}$ and the $\mathrm{Pt}$ atom of $\mathrm{NH}_{3}$-Pt. XGU was modified for $\mathrm{G} 7$ by combining the $\mathrm{Pt}\left(\mathrm{NH}_{3}\right)_{2}$ moiety with $\mathrm{N} 7$ of the $\underline{\mathrm{G}} 7$ residue. The new bonds, angles, dihedral angles, and force constants were obtained from ref 44 . An initial extended structure was produced from the duplex sequence. Two types of constraints were used in the structure calculations: experimentally derived and halonomic distance constraints. A total of 551 and 920 NOE-derived distance restraints were employed in the structure calculations for $\mathrm{CP}-\mathrm{GG}$ DNA and undamaged DNA, respectively. The NOE cross- 
peaks were standardized to the Cyt H5-H6 cross-peaks, with a H5-H6 distance of $2.5 \AA$. One additional angstrom was added for distance constraints involving methyl groups.

Planarity was also restrained for all base pairs (45) with the exception of the base pairs associated with the $\mathrm{CP}$ adduct, where the force constant was reduced by half. Although the sugar pucker conformation was estimated from analysis of NOE constraints and simulations of cross-peaks in DQF-COSY spectra to encompass both A and B DNA conformations, a broad range of torsion angle restraints were employed for the sugar-phosphate torsion angles, i.e., $\mathrm{a}\left(-70 \pm 50^{\circ}\right), \beta\left(180 \pm 50^{\circ}\right), \gamma\left(60 \pm 35^{\circ}\right), \zeta\left(-85 \pm 50^{\circ}\right), \chi\left(-120 \pm 50^{\circ}\right), \delta$ $\left(120 \pm 50^{\circ}\right)$, and $\mathcal{\varepsilon}\left(180 \pm 50^{\circ}\right)$ in the structure calculations. Finally, six distance restraints per base pair were employed to describe Watson-Crick base pairing (45). The lower and upper bounds for $\mathrm{H}$-bond distance constraints were set to $7 \%$. However, for base pairs associated with the $\mathrm{CP}$ adduct, the bounds were increased to $10 \%$. Of 20 calculated structures, the 15 with the lowest energy were accepted as a family.

\section{RESULTS AND DISCUSSION}

\section{Characterization of the Cisplatin-GG Intrastrand Cross-Link}

The purity of the CP-adducted GG strand was $>95 \%$ as determined by HPLC and denaturing gel electrophoresis (see Materials and Methods). Following hybridization with the complementary strand, the CP-GG 12-mer duplex was further characterized following the same procedure reported by Wu et al. (26) for the OX-GG 12-mer duplex. Both undamaged 12-mer duplex and 12-mer duplex containing the CP-GG intrastrand cross-link were digested to the deoxynucleoside and $\mathrm{CP}[\mathrm{d}(\mathrm{GpG})]$ level, respectively, with a combination of deoxyribonuclease I, nuclease P1, and alkaline phosphatase as described by Eastman (46) and were characterized by HPLC-UV-MS. Using this procedure, the Pt-GG intrastrand cross-link is digested to Pt[d(GpG)], the Pt-AG intrastrand cross-link to Pt[d(ApG)], and the Pt-G monoadduct to Pt(dG). In addition, both the GNG intrastrand cross-link and the GG interstrand cross-link are digested to dG-Pt-dG (46). The HPLC-UV chromatogram of the digestion products derived from the undamaged 12-mer duplex exhibited four peaks (Figure $2, \mathrm{I})$. These peaks were identified as $\mathrm{dC}, \mathrm{dT}, \mathrm{dG}$, and $\mathrm{dA}$ on the basis of their retention time, UV spectrum, and mass spectra (data not shown) that were identical to those of authentic standards (data not shown). The relative abundance of the individual deoxynucleosides was as expected for the 12-mer duplex. The 12-mer duplex containing the $\mathrm{CP}-\mathrm{GG}$ intrastrand cross-link showed the four normal deoxynucleosides and one additional peak eluting just before dG (Figure 2, IIA). This additional digestion product had the same retention time and UV spectrum as the synthetic $\mathrm{CP}[\mathrm{d}(\mathrm{GpG})]$ standard (data not shown). This additional peak was further identified as $\mathrm{CP}[\mathrm{d}(\mathrm{GpG})]$ by the presence of the expected molecular ions in both the positive $(\mathrm{m} / z$ 824.89) (Figure 2, IIB) and negative $(\mathrm{m} / z$ 822.90) (data not shown) modes. In addition, the presence of a peak with a mass of 806.98 (positive $\mathrm{m} / \mathrm{z} 808.01$ and negative $\mathrm{m} / \mathrm{z}$ 805.93) corresponds to the molecular weight of $\mathrm{CP}[\mathrm{d}(\mathrm{GpG})]$ after dissociation of an ammonia molecule of cisplatin (Figure 2, IIB). Last, the MS spectra also showed the expected Pt isotopes, confirming the presence of a Pt compound. No digestion products were detected with the masses and isotopic pattern expected for the dG-CP-dG, CP[d(ApG)], or $\mathrm{CP}(\mathrm{dG})$ adducts (data not shown). These data demonstrate that the 12-mer duplex employed in this NMR study consisted exclusively of the $\mathrm{CP}-\mathrm{GG}$ intrastrand cross-link. The lack of any detectable $\mathrm{CP}-\mathrm{AG}$ intrastrand cross-link is consistent with previous reports that the $\mathrm{Pt}-$ AG diadduct comprises less than 3\% of the total Pt intrastrand cross-links formed in the AGG sequence context $(26,47)$. 


\section{Proton Assignments}

Chemical shift assignments for both the $\mathrm{CP}$ and undamaged DNA samples were obtained as described previously for the OX-GG adduct in the same 12-mer duplex (26). Assignments of the nonexchangeable base and sugar protons were obtained by analysis of NOESY spectra recorded in $\mathrm{D}_{2} \mathrm{O}$ buffer at $25^{\circ} \mathrm{C}$. For example, the NOESY region for the CP-DNA duplex in Figure 3 shows NOE correlations between the base (purine H8/pyrimidine H6) and the $\mathrm{H}^{\prime}{ }^{\prime}$ sugar protons and between the base (purine $\mathrm{H} 8$ /pyrimidine $\mathrm{H} 6$ ) and the $\mathrm{H} 2^{\prime}$ and $\mathrm{H} 2$ " sugar protons. Sequential connectivities can be observed without interruptions from $\mathrm{C} 1$ to $\mathrm{C} 12$ in the GG strand and from G13 to G24 in the CC strand. Comparable data for the undamaged DNA are shown in Figure S1 of the Supporting Information. Once sequential assignments were obtained for $\mathrm{H} 8 / \mathrm{H} 6, \mathrm{H}^{\prime}{ }^{\prime}, \mathrm{H} 2^{\prime}$, and $\mathrm{H} 2^{\prime \prime}$, the assignments of the other $\left(\mathrm{H}^{\prime}, \mathrm{H}^{\prime}, \mathrm{H} 5^{\prime}\right.$, and $\mathrm{H} 5^{\prime \prime}$ ) sugar protons were extended on the basis of the NOESY, DQFCOSY, and TOCSY spectra, following standard procedures (41). Assignments of the exchangeable protons were obtained by analyzing distance connectivities between the imino and base/amino proton regions of NOESY spectra in $\mathrm{H}_{2} \mathrm{O}$ buffer at $2{ }^{\circ} \mathrm{C}$. The chemical shift assignments for the CP-DNA duplex and undamaged DNA are listed in Tables S1 and S2 of the Supporting Information, respectively.

Previous NMR studies of Pt-GG adducts have examined a single type of adduct ( $\mathrm{CP}$ or $\mathrm{OX}$ ) in a single sequence context and have compared both the proton chemical shifts and NOE cross-peak intensities with average values for undamaged B-DNA in a variety of sequence contexts $(24,25,27,33)(34)$. However, it is unclear whether some of the observed differences are due to differences in sequence context rather than between the platinated and unplatinated strand. We are in a unique position to directly determine the effect of Pt-GG adducts on both the proton chemical shifts and NOE cross-peak intensities of the DNA in the region of the Pt-GG adduct, as our NMR data were collected on OX-GG DNA (26), CP-GG DNA, and undamaged B-DNA in the same AGGC sequence context. Chemical shift differences among OX-GG DNA, CP-GG DNA, and undamaged B-DNA for the H6/H8, $\mathrm{H} 1^{\prime}, \mathrm{H} 2^{\prime}$, and $\mathrm{H} 2^{\prime \prime}$ protons are shown in Figure 4. It is clear from this comparison that the formation of Pt-GG adducts primarily affects chemical shifts of protons within the central 4 bp region. Moreover, a larger difference in chemical shifts is observed for protons on the strand containing the adduct relative to the complementary strand. Both the CP-GG and OX-GG adducts exhibited downfield chemical shifts for the H8 proton of both $\underline{\mathrm{G}} 6$ and $\underline{\mathrm{G}} 7$, the $\mathrm{H} 6$ proton of $\mathrm{C} 8$, and the $\mathrm{H} 1^{\prime}$ protons of $\mathrm{A} 5, \underline{\mathrm{G}} 6$, and $\mathrm{C} 8$. In contrast, upfield chemical shifts were observed for the $\mathrm{H} 1^{\prime}$ proton of $\underline{\mathrm{G}} 7$, the $\mathrm{H} 2^{\prime}$ proton of $\underline{\mathrm{G}} 6$ and $\underline{\mathrm{G}} 7$, and the $\mathrm{H} 2^{\prime \prime}$ proton of $\underline{\mathrm{G}} 7$.

Previous studies have not made direct comparisons of platinated adducts with undamaged DNA in the same sequence context and thus were unable to determine the effect of Pt-DNA adducts on proton chemical shifts with this precision. However, downfield chemical shifts have been reported for the $\mathrm{H} 8$ protons of the $5^{\prime}$ and $3^{\prime} \mathrm{G}$ residues for all Pt-GG adducts studied to date (24-26, 33), so this has been considered a universal feature of Pt-GG adducts. In their analysis of a CP-GG adduct, Marzilli et al. (25) reported a much greater downfield chemical shift for the $\mathrm{H} 8$ proton on the $5^{\prime} \mathrm{G}$ residue than for the $3^{\prime} \mathrm{G}$ residue and a significant upfield shift of the $\mathrm{H} 2^{\prime}$ proton on the $\mathrm{C}$ complementary to the $5^{\prime} \mathrm{G}$ residue, which they considered universal features of all $\mathrm{CP}-\mathrm{GG}$ adducts. However, we do not observe either of these features in direct comparisons of the CP-GG DNA (Table S1) adducts with undamaged DNA (Table S2), so these chemical shifts do not appear to be features of all CP-GG adducts. Our adducts differ from all previous adducts in that they are in the $\mathrm{AGGC}$ sequence context, so the differences in proton chemical shifts between our PtGG adducts and the $\mathrm{CP}-\mathrm{GG}$ adduct reported by Marzilli et al. (25) may reflect an effect of

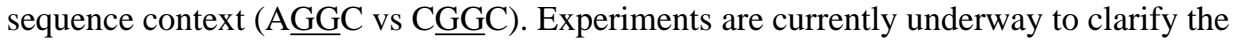
effect of sequence context on NMR data and conformation of the Pt-GG adducts. 
With respect to NOE cross-peaks (Table S3 of the Supporting Information) for both CP-GG and $\mathrm{OX}-\mathrm{GG}$ adducts, we observed stronger $\underline{\mathrm{G}} 6 \mathrm{H} 8-\underline{\mathrm{G}} 7 \mathrm{H} 8 \mathrm{NOE}$ cross-peaks and weaker A5 $\mathrm{H} 1^{\prime}$ - 66 H8 and $\underline{\mathrm{G}} 6 \mathrm{H}^{\prime}{ }^{\prime}-\underline{\mathrm{G}} 7 \mathrm{H} 8$ cross-peaks compared to those in undamaged DNA, consistent with data reported previously for other CP-GG adducts. We also see some significant difference in NOE cross-peak intensities between CP-GG and OX-GG adducts. Marzilli et al. (25) had previously suggested that an unusually weak NOE cross-peak between $\mathrm{H} 2^{\prime}$ of the $\mathrm{C}$ complementary to the $5^{\prime} \mathrm{G}$ residue and $\mathrm{H} 6 / \mathrm{H} 8$ of the base complementary to the $5^{\prime}$ flanking base was a universal feature of all CP-GG adducts. Here, we find that the $\mathrm{C} 19 \mathrm{H}^{\prime}{ }^{\prime}-\mathrm{T} 20 \mathrm{H} 6 \mathrm{NOE}$ cross-peak for the $\mathrm{CP}-\mathrm{GG}$ adduct in the AGGC sequence context is also weaker than that in undamaged DNA (Table S3). In contrast, we have previously reported (26) that the NOE cross-peak between $\mathrm{C} 19 \mathrm{H}^{\prime}{ }^{\prime}$ and T20 H6 for the OX-GG adduct was near normal. In addition, compared to the OX-DNA adduct, the CP-DNA adduct exhibited a stronger $\underline{\mathrm{G}} 6 \mathrm{H}^{1}{ }^{\prime}$ - $\underline{\mathrm{G}} 7 \mathrm{H} 8 \mathrm{NOE}$ cross-peak and a weaker $\underline{\mathrm{G}} 6$ H8- 7 7 H8 NOE cross-peak (Table S3). These differences in NOE cross-peak intensity are consistent with the differences in DNA helical parameters of CP- and OX-DNA adducts, such as the differences observed for the twist in the A5 T20 ${ }^{\circ} 6$ C19 base pair step and twist and roll in the $\underline{\mathrm{G}} 6 \mathrm{C} 19 \cdot \underline{\mathrm{G}} 7 \mathrm{C} 18$ base pair step (see below).

The CP-GG and OX-GG adducts also differ significantly from each other in that the extent of the downfield chemical shift for the $\underline{\mathrm{G}} 7 \mathrm{H} 8$ and $\underline{\mathrm{G}} 6 \mathrm{H} 1^{\prime}$ protons and the upfield chemical shift of the A5 and $\underline{\mathrm{G}} 6 \mathrm{H} 2^{\prime}$ protons was significantly greater for the $\mathrm{CP}-\mathrm{GG}$ adduct than the OX-GG adduct (Figure 4). The difference in the chemical shift of the $\underline{\mathrm{G}} 7 \mathrm{H} 8$ proton is particularly interesting because it could theoretically arise from a difference in the canting of the $3^{\prime} \mathrm{G}$ residue in relation to the $5^{\prime} \mathrm{G}$ residue for the $\mathrm{OX}-\mathrm{GG}$ and $\mathrm{CP}-\mathrm{GG}$ adducts. The degree of base canting for both the $5^{\prime}$ and $3^{\prime} \mathrm{G}$ residues was determined by measuring the C5-N7-Pt-cis N and C8-N7-Pt-cis N dihedral angles (48) (Table S4 of the Supporting Information). However, no significant differences were observed in these dihedral angles for the OX-GG and CP-GG adducts. It is likely that the differences in $\underline{\mathrm{G}} 7 \mathrm{H} 8$ chemical shifts between the $\mathrm{OX}-\mathrm{GG}$ and $\mathrm{CP}-\mathrm{GG}$ adducts result from the anisotropic effects of the $\left(\mathrm{NH}_{3}\right)_{2} \mathrm{Pt}$ and 1,2-diaminocyclohexane-Pt moieties, since sequence context and buffer conditions were identical.

\section{Temperature Dependence of Imino-Solvent Exchange}

The temperature dependence of the imino proton resonances associated with the duplexes (Figure 5) was monitored by $1 \mathrm{D}^{1} \mathrm{H}$ NMR in $\mathrm{H}_{2} \mathrm{O}$ buffer solution [100 $\mathrm{mM} \mathrm{NaCl}$ and $5 \mathrm{mM}$ $\mathrm{Na}_{2} \mathrm{HPO}_{4} / \mathrm{NaH}_{2} \mathrm{PO}_{4}$ (pH 7.0)] at temperatures ranging from 2 to $40{ }^{\circ} \mathrm{C}$. For both CP-DNA and OX-DNA duplexes, the imino peaks of $\underline{\mathrm{G}} 6$ and $\underline{\mathrm{G}} 7$ totally disappear while other imino peaks survive at $40{ }^{\circ} \mathrm{C}$, indicating that the binding of both $\mathrm{CP}$ and $\mathrm{OX}$ results in enhanced solvent accessibility of the $\underline{\mathrm{G}} 6$ and $\underline{\mathrm{G}} 7$ guanines. These data are consistent with previous reports for other Pt-GG intrastrand cross-links (24). Moreover, for both $\mathrm{CP}$ and $\mathrm{OX}$, the imino peak for $\mathrm{G} 6$ shows a greater loss of intensity at $25^{\circ} \mathrm{C}$ relative to the imino peak for $\mathrm{G} 7$, suggesting that the exchange rate for the $\underline{\mathrm{G}} 6$ imino proton is faster than for the $\underline{\mathrm{G}} 7$ imino proton. These observations are consistent with previous reports for other Pt-GG adducts (24, 25,33 ) and suggest that both the $\mathrm{CP}$ and $\mathrm{OX}$ adducts may be more distorted and/or flexible on the $5^{\prime}$ side of the adduct than on the $3^{\prime}$ side.

\section{Assignment of ${ }^{31} \mathrm{P}$ Resonances}

Phosphorus chemical shifts are influenced strongly by backbone torsion angles. To investigate the effects of the $\mathrm{CP}-\mathrm{GG}$ adduct on the phosphodiester backbone conformation, $2 \mathrm{D}{ }^{1} \mathrm{H}-{ }^{31} \mathrm{P}$ HETCOR spectra were recorded for both the CP-DNA duplex and undamaged DNA (Figure S2A,B of the Supporting Information). Phosphorus signals were assigned from the $\mathrm{H}^{\prime}(i)-\mathrm{P}(i)$ and $\mathrm{P}(i)-\mathrm{H}^{\prime}{ }^{\prime}(i+1)$ cross-peaks with the chemical shifts of the phosphorus 
atoms listed in Tables S1 and S2. All backbone phosphate resonances of the CP-GG 12-mer duplex were dispersed between -3.41 and $-4.50 \mathrm{ppm}$ over a range of $1.09 \mathrm{ppm}$. This is only slightly larger than the range ( -3.80 to $-4.40 \mathrm{ppm})$ observed for the phosphodiester backbone in undamaged B-DNA. Marzilli et al. (25) reported that for their CP-GG adduct the ${ }^{31} \mathrm{P}$ signal for the phosphate group between the two $\mathrm{G}$ residues coordinated to platinum was significantly shifted downfield (to $-3.08 \mathrm{ppm}$ ). However, we find almost no difference in the chemical shift of the ${ }^{31} \mathrm{P}$ signal among the CP-DNA duplex (Table S1), the OX-DNA duplex (26), and undamaged DNA (Table S2). These data indicate that the formation of a $\mathrm{CP}-$ or $\mathrm{OX}-\mathrm{GG}$ adduct in the AGGC sequence context does not significantly perturb the DNA backbone.

\section{J Coupling Constants and Sugar Pucker Estimates}

Figure 6 shows an expanded portion of the $\mathrm{H} 1^{\prime}-\mathrm{H} 2^{\prime}$ and $\mathrm{H} 1^{\prime}-\mathrm{H} 2^{\prime \prime}$ region of the DQFCOSY spectra for the undamaged DNA and CP-DNA duplex at $25^{\circ} \mathrm{C}$ in $\mathrm{D}_{2} \mathrm{O}$ with the A5, G6, and G7 cross-peaks indicated by the dotted lines. The relative intensity of the $\mathrm{H} 1^{\prime}-\mathrm{H} 2^{\prime \prime}$ and $\mathrm{H} 1^{\prime}-\mathrm{H} 2^{\prime} \mathrm{DQF}-\mathrm{COSY}$ cross-peak reflects the relative size of the coupling between these sugar protons and can be used to provide information about sugar conformation (25, 49). Sugars with a $C 2^{\prime}$-endo $(S)$ conformation give fairly weak $\mathrm{H} 1^{\prime}-\mathrm{H} 2^{\prime \prime}$ and strong $\mathrm{H} 1^{\prime}-$ $\mathrm{H} 2^{\prime}$ DQF-COSY cross-peaks, while sugars with near- $C 3^{\prime}$-endo $(N)$ conformations give the opposite relative intensity pattern. To obtain sugar pucker for both the CP-DNA duplex and undamaged DNA, the procedure reported previously for the OX-DNA adduct was used (26). J coupling constants were obtained by simulating DQF-COSY cross-peaks using Chords version 2.0. Tables S5 and S6 of the Supporting Information list the $J$ coupling constants obtained for all residues except terminal residues for the CP-DNA duplex and undamaged DNA, respectively. The sums of the $\mathrm{H} 1^{\prime} J$ coupling constants, $\Sigma 1^{\prime}$, were used to calculate fractions of south $\left(C 2^{\prime}\right.$-endo), $f_{\mathrm{s}}$, conformers for each sugar residue by assuming a two-state dynamic equilibrium and using the equation

$$
f_{\mathrm{s}}=\left(\sum 1^{\prime}-9.8\right) / 5.9
$$

where $\Sigma 1^{\prime}=J_{\mathrm{H} 1^{\prime}-\mathrm{H} 2^{\prime}}+J_{\mathrm{H} 1^{\prime}-\mathrm{H} 2^{\prime \prime}}$.

Table 1 summarizes the assigned sugar pucker $\left(x_{\mathrm{c}} 4_{\mathrm{s}}\right)$ for undamaged DNA, the CP-GG adduct, and the OX-GG adduct. For the undamaged DNA, all sugar puckers have the $S$ conformation, including A5, G6, and G7. In contrast, for the OX-GG adduct, the G6 sugar pucker was found to be mostly $N$ and the A5 sugar pucker primarily $S$, but with some $N$ characteristics (26). For the CP-GG adduct, both the A5 and G6 sugar puckers are intermediate between $S$ and $N$. The other residues have primarily the $S$ sugar pucker, characteristic of B-DNA. These data are consistent with previous reports $(24,25)$ and indicate that compared to undamaged DNA, platinated DNA adducts exhibit distortion only in the sugar rings for the $5^{\prime} \underline{\mathrm{G}}$ residue and the base $5^{\prime}$ to the $\underline{\mathrm{G}}$.

\section{Structure Calculations}

We obtained 551 and 920 experimental distance constraints for the CP-DNA duplex and undamaged DNA, respectively, from the 200 ms NOESY spectra in both $\mathrm{H}_{2} \mathrm{O}$ and $\mathrm{D}_{2} \mathrm{O}$. These experimental distance constraints were then used as input for CNS to calculate the respective solution structures of the CP-DNA duplex and undamaged DNA. Additional constraints included base pair constraints between heavy atoms involved in hydrogen bonding and a planarity constraint to keep the base pairs in a plane (45). Force constants and charges for $\mathrm{CP}$ bound to the two $\mathrm{G}$ residues were obtained as described in Materials and 
Methods. The structural parameter statistics for the CP-DNA duplex and undamaged DNA are listed in Table 2. Of 20 calculated structures for each DNA, the 15 with the lowest energy were accepted as a family. The rmsd for the superimposition of the non-H atoms for all 15 final structures was $0.81 \AA$ for the CP-DNA duplex and 1.21 for undamaged DNA, which indicates good convergence for both structures. The fact that there were no distance and dihedral angle restraint violations $>0.5 \AA$ and $5^{\circ}$, respectively, indicated that the final structures satisfied the imposed experimental restraints. The stereoviews of the average solution structures obtained for the CP-DNA duplex and undamaged DNA are shown in Figure 7.

\section{Accuracy of the Structures}

To verify the accuracy of the structures, theoretical NOESY spectra were back-calculated from the average final structure and known chemical shifts using the Model module and the matrix-doubling capability (MSI) of Felix. The accuracy of the computed structure can be judged by comparing the back-calculated NOEs with the experimental 2D NOE data. The comparison of experimental and back-calculated NOEs for the entire molecule is shown in Figures S3 and S4 of the Supporting Information for undamaged DNA and the CP-DNA duplex, respectively. Experimental cross-peak volumes were compared to their theoretical counterparts to compute $R$-factors:

$$
\begin{gathered}
R^{\mathrm{c}}=\frac{\sum_{i}\left|I_{\mathrm{ei}}-I_{\mathrm{ti}}\right|}{\sum_{i} I_{\mathrm{ei}}} \\
R^{\mathrm{x}}=\frac{\sum_{i}\left|I_{\mathrm{ei}}^{1 / 6}-I_{\mathrm{ti}}^{1 / 6}\right|}{\sum_{i} I_{\mathrm{ei}}^{1 / 6}}
\end{gathered}
$$

in which $R^{\mathrm{C}}$ is the crystallographic-equivalent $R$-factor, $R^{\mathrm{x}}$ is the sixth-root residual index, and $I_{\mathrm{e}}$ and $I_{\mathrm{t}}$ are the experimental and theoretical cross-peak volumes for the $i$ th cross-peak, respectively. $R$-Factors were computed for the NOESY experiments (mixing time of 300 $\mathrm{ms}$ ). For undamaged DNA, $R^{\mathrm{C}}$ and $R^{\mathrm{x}}$ values of the average structure were 0.21 and 0.04 , respectively. For the CP-DNA duplex, $R^{\mathrm{c}}$ and $R^{\mathrm{x}}$ values of the average structure were 0.16 and 0.04 , respectively. The obtained $R$-factors indicate that the structures are in good agreement with the measured NOEs.

\section{Comparison with CP-DNA and OX-DNA Conformations}

We are able to directly compare the solution structures of the CP-GG and OX-GG (26) adducts in the AGGC sequence context, since the DNA sequences are identical and the NMR data and structural calculations were performed in the same manner as our previous structural study of the OX-GG adduct (26). The platinum geometry is compared in Table S7 of the Supporting Information. However, as the location of the platinum atom is not determined by NMR constraints, the significance of these observations is unclear. An overlay of the central 4 bp of the CP-DNA duplex with undamaged DNA and with the OXDNA duplex (26) is shown in Figure 7, and selected DNA helical parameters are compared in Table 3. The CP-GG and OX-GG adducts differ significantly in terms of twist at the A5G6 base pair step, slide, twist, and roll at the $\underline{\mathrm{G} 6}-\underline{\mathrm{G}} 7$ base pair step, slide at the $\underline{\mathrm{G}} 7-\mathrm{C} 8$ base pair step, buckle for the $\underline{\mathrm{G}} 6{ }^{\circ} \mathrm{C} 19$ base pair, opening for the $\underline{\mathrm{G}} 7 \cdot \mathrm{C} 18$ base pair, $\underline{\mathrm{G}} 6-\underline{\mathrm{G}} 7$ 
dihedral angle, and overall bend. One or more of these conformational differences may be important for the differential recognition of $\mathrm{CP}-\mathrm{GG}$ and $\mathrm{OX}-\mathrm{GG}$ adducts by some mismatch repair proteins, DNA binding proteins (including certain transcription factors), and DNA polymerases. For example, the HMG domain of HMG-B1 has been shown to bind with higher efficiency to CP-GG adducts than to OX-GG adducts (14), and a crystal structure of the HMG-CP-DNA complex has been reported (31). The DNA helical parameters for the HMG-CP-DNA complex have been included in Table 3 for comparison. Many of the DNA helical parameters for the DNA-adduct complex differ from those of the solution structures of both the CP-GG and OX-GG adducts, which probably reflects the severe DNA distortion imposed by binding of the HMG protein. However, the twist at the A5- $\underline{\mathrm{G}} 6$ and $\underline{\mathrm{G}} 6-\underline{\mathrm{G}} 7$ base pair steps and slide at the $\underline{\mathrm{G}} 7-\mathrm{C} 8$ base pair steps for the HMG-CP-GG DNA complex are much closer to those of the $\mathrm{CP}-\mathrm{GG}$ solution structure than the $\mathrm{OX}-\mathrm{GG}$ solution structure. If any of these conformations are characteristic of the protein-DNA conformation in the initial recognition step, this may facilitate recognition of the $\mathrm{CP}-\mathrm{GG}$ adduct by the HMG domain. The conformational difference at the $\underline{\mathrm{G}} 7-\mathrm{C} 8$ base pair step might be particularly critical because both the affinity of the HMG domain for the CP-GG adduct $(14,50,51)$ and the ability of the HMG domain to discriminate between CP-GG and OX-GG adducts (14) are highly dependent on the base to the $3^{\prime}$ side of the adduct. There are, of course, a number of important limitations inherent in this type of comparison. First, we are comparing a crystal structure of the HMG-CP-GG DNA complex with the solution structures of the CP-GG and OX-GG DNA adducts. Second, it is likely that the final, stable protein-DNA complex has a conformation different from that of the initial protein-DNA recognition complex. Third, the sequence context of the $\mathrm{CP}-\mathrm{GG}$ adduct in the $\mathrm{HMG}-\mathrm{CP}-\mathrm{GG}$ complex differs from that in the $\mathrm{CP}-\mathrm{GG}$ and $\mathrm{OX}-\mathrm{GG}$ solution structures. Hence, experiments are underway to determine solution NMR structures of CP-GG and OX-GG adducts in complex with an HMG domain from one or more proteins that discriminate between these adducts, in the same AGGC sequence context, to better characterize conformational differences that are important for differential protein recognition of the adducts.

\section{Supplementary Material}

Refer to Web version on PubMed Central for supplementary material.

\section{References}

1. Greene MH. Is Cisplatin a Human Carcinogen. J Natl Cancer Inst. 1992; 84:306-312. [PubMed: 1738180]

2. Travis LB, Curtis RE, Storm H, Hall P, Holowaty E, Van Leeuwen FE, Kohler BA, Pukkala E, Lynch CF, Andersson M, Bergfeldt K, Clarke EA, Wiklund T, Stoter G, Gospodarowicz M, Sturgeon J, Fraumeni JF Jr, Boice JD Jr. Risk of second malignant neoplasms among long-term survivors of testicular cancer. J Natl Cancer Inst. 1997; 89:1429-1439. [PubMed: 9326912]

3. Silva MJ, Costa P, Dias A, Valente M, Louro H, Boavida MG. Comparative analysis of the mutagenic activity of oxaliplatin and cisplatin in the Hprt gene of CHO cells. Environ Mol Mutagen. 2005; 46:104-115. [PubMed: 15887215]

4. Bassett E, King NM, Bryant MF, Hector S, Pendyala L, Chaney SG, Cordeiro-Stone M. The role of DNA polymerase $\eta$ in translesion synthesis past platinum-DNA adducts in human fibroblasts. Cancer Res. 2004; 64:6469-6475. [PubMed: 15374956]

5. Page JD, Husain I, Sancar A, Chaney SG. Effect of the diaminocyclohexane carrier ligand on platinum adduct formation, repair, and lethality. Biochemistry. 1990; 29:1016-1024. [PubMed: 2340275]

6. Jennerwein MM, Eastman A, Khokhar AR. Characterization of adducts produced in DNA by isomeric 1, 2-diaminocyclohexaneplatinum(II) complexes. Chem -Biol Interact. 1989; 70:39-49. [PubMed: 2736676] 
7. Woynarowski JM, Chapman WG, Napier C, Herzig MCS, Juniewicz P. Sequence- and regionspecificity of oxaliplatin adducts in naked and cellular DNA. Mol Pharmacol. 1998; 54:770-777. [PubMed: 9804612]

8. Fink D, Nebel S, Aebi S, Zheng H, Cenni B, Nehme A, Christen RD, Howell SB. The role of mismatch repair in platinum drug resistance. Cancer Res. 1996; 56:4881-4886. [PubMed: 8895738]

9. Zdraveski ZZ, Mello JA, Farinelli CK, Essigmann JM, Marinus MG. MutS preferentially recognizes cisplatin- over oxaliplatin-modified DNA. J Biol Chem. 2002; 277:1255-1260. [PubMed: 11705991]

10. Aebi S, Kurdihaidar B, Gordon R, Cenni B, Zheng H, Fink D, Christen RD, Boland CR, Koi M, Fishel R, Howell SB. Loss of DNA mismatch repair in acquired resistance to cisplatin. Cancer Res. 1996; 56:3087-3090. [PubMed: 8674066]

11. Fink D, Zheng H, Nebel S, Norris PS, Aebi S, Lin T-P, Nehme A, Christen RD, Haas M, MacLeod CL, Howell SB. In vitro and in vivo resistance to cisplatin in cells that have lost DNA mismatch repair. Cancer Res. 1997; 57:1841-1845. [PubMed: 9157971]

12. Vaisman A, Varchenko M, Umar A, Kunkel TA, Risinger JI, Barrett JC, Hamilton TC, Chaney SG. The role of hMLH1, hMSH3, and hMSH6 defects in cisplatin and oxaliplatin resistance: Correlation with replicative bypass of platinum-DNA adducts. Cancer Res. 1998; 58:3579-3585. [PubMed: 9721864]

13. Brown R, Hirst GL, Gallagher WM, Mcilwrath AJ, Margison GP, Vanderzee AGJ, Anthoney DA. hMLH1 expression and cellular responses of ovarian tumour cells to treatment with cytotoxic anticancer agents. Oncogene. 1997; 15:45-52. [PubMed: 9233776]

14. Wei M, Cohen SM, Silverman AP, Lippard SJ. Effects of spectator ligands on the specific recognition of intrastrand platinum-DNA cross-links by high mobility group box and TATAbinding proteins. J Biol Chem. 2001; 276:38774-38780. [PubMed: 11514569]

15. Zhai X, Beckmann H, Jantzen H-M, Essigmann JM. Cisplatin-DNA adducts inhibit ribosomal RNA synthesis by hijacking the transcription factor human upstream binding factor. Biochemistry. 1998; 37:16307-16315. [PubMed: 9819223]

16. Huang JC, Zamble DB, Reardon JT, Lippard SJ, Sancar A. HMG-domain proteins specifically inhibit the repair of the major DNA adduct of the anticancer drug cisplatin by human excision nuclease. Proc Natl Acad Sci U S A. 1994; 91:10394-10398. [PubMed: 7937961]

17. Mcanulty MM, Lippard SJ. The HMG-domain protein Ixr1 blocks excision repair of cisplatinDNA adducts in yeast. Mutat Res. 1996; 362:75-86. [PubMed: 8538651]

18. Hoffmann JS, Locker D, Viliani G, Leng M. HMG1 protein inhibits the translesion synthesis of the major DNA cisplatin adduct by cell extracts. J Mol Biol. 1997; 270:539-543. [PubMed: 9245584]

19. Vaisman A, Lim SE, Patrick SM, Copeland WC, Hinkle DC, Turchi JJ, Chaney SG. Effect of DNA Polymerases and High Mobility Group Protein 1 on the Carrier Ligand Specificity for Translesion Synthesis past Platinum-DNA Adducts. Biochemistry. 1999; 38:11026-11039. [PubMed: 10460158]

20. Treiber DK, Zhai XQ, Jantzen HM, Essigmann JM. Cisplatin-DNA adducts are molecular decoys for the ribosomal RNA transcription factor hUBF (human upstream binding factor). Proc Natl Acad Sci U S A. 1994; 91:5672-5676. [PubMed: 8202546]

21. Coin F, Frit P, Viollet B, Salles B, Egly JM. TATA binding protein discriminates between different lesions on DNA, resulting in a transcription decrease. Mol Cell Biol. 1998; 18:3907-3914. [PubMed: 9632775]

22. Vaisman A, Masutani C, Hanaoka F, Chaney SG. Efficient translesion replication past oxaliplatin and cisplatin GpG adducts by human DNA polymerase $\eta$. Biochemistry. 2000; 39:4575-4580. [PubMed: 10769112]

23. Vaisman A, Chaney SG. The efficiency and fidelity of translesion synthesis past cisplatin and oxaliplatin GpG adducts by human DNA polymerase $\beta$. J Biol Chem. 2000; 275:13017-13025. [PubMed: 10777605]

24. Gelasco A, Lippard SJ. NMR solution structure of a DNA dodecamer duplex containing a cisdiammineplatinum-(II) dGpG intrastrand cross-link, the major adduct of the anticancer drug cisplatin. Biochemistry. 1998; 37:9230-9239. [PubMed: 9649303] 
25. Marzilli LG, Saad JS, Kuklenyik Z, Keating KA, Xu Y. Relationship of solution and protein-bound structures of DNA duplexes with the major intrastrand cross-link lesions formed on cisplatin binding to DNA. J Am Chem Soc. 2001; 123:2764-2770. [PubMed: 11456962]

26. Wu Y, Pradhan P, Havener J, Boysen G, Swenberg JA, Campbell SL, Chaney SG. NMR solution structure of an oxaliplatin 1, 2-d(GG) intrastrand cross-link in a DNA dodecamer duplex. J Mol Biol. 2004; 341:1251-1269. [PubMed: 15321720]

27. Takahara PM, Frederick CA, Lippard SJ. Crystal structure of the anticancer drug cisplatin bound to duplex DNA. J Am Chem Soc. 1996; 118:12309-12321.

28. Spingler B, Whittington DA, Lippard SJ. 2.4 A crystal structure of an oxaliplatin 1,2-d(GpG) intrastrand cross-link in a DNA dodecamer duplex. Inorg Chem. 2001; 40:5596-5602. [PubMed: 11599959]

29. Lamers MH, Perrakis A, Enzlin JH, Winterwerp HHK, de Wind N, Sixma TK. The crystal structure of DNA mismatch repair protein MutS binding to a $\mathrm{G}$ center dot $\mathrm{T}$ mismatch. Nature. 2000; 407:711-717. [PubMed: 11048711]

30. Obmolova G, Ban C, Hsieh P, Yang W. Crystal structures of mismatch repair protein MutS and its complex with a substrate DNA. Nature. 2000; 407:703-710. [PubMed: 11048710]

31. Ohndorf UM, Rould MA, He Q, Pabo CO, Lippard SJ. Basis for recognition of cisplatin-modified DNA by high-mobility-group proteins. Nature. 1999; 399:708-712. [PubMed: 10385126]

32. Sawaya MR, Prasad R, Wilson SH, Kraut J, Pelletier H. Crystal structures of human DNA polymerase $\beta$ complexed with gapped and nicked DNA: Evidence for an induced fit mechanism. Biochemistry. 1997; 36:11205-11215. [PubMed: 9287163]

33. Yang D, van Bloom SSGE, Reedijk J, van Bloom JH, Wang AHJ. Structure and isomerization of an intrastrand cisplatin-cross-linked octamer DNA duplex by NMR analysis. Biochemistry. 1995; 34:12912-12920. [PubMed: 7548048]

34. Herman F, Kozelka J, Stoven V, Guittet E, Girault JP, Huynh-Dinh T, Igolen J, Lallemand JY, Chottard JC. A d(GpG)-platinated decanucleotide duplex is kinked. An extended NMR and molecular mechanics study. Eur J Biochem. 1990; 194:119-133. [PubMed: 2174772]

35. Bubley GJ, Ashburner BP, Teicher BA. Spectrum of cis-diamminedichloroplatinum(II)-induced mutations in a shuttle vector propagated in human cells. Mol Carcinog. 1991; 4:397-406. [PubMed: 1910483]

36. de Boer JG, Glickman BW. Sequence specificity of mutations induced by the antitumor drug cisplatin in the CHO aprt gene. Carcinogenesis. 1989; 10:1363-1367. [PubMed: 2752512]

37. de Boer JG, Glickman BW. Mutations Recovered in the Chinese Hamster aprt Gene After Exposure to Carboplatin: A Comparison with Cisplatin. Carcinogenesis. 1992; 13:15-17. [PubMed: 1733567]

38. Pillaire MJ, Margot A, Villani G, Sarasin A, Defais M, Gentil A. Mutagenesis in monkey cells of a vector containing a single d(GPG) cis-diamminedichloroplatinum(II) adduct placed on codon 13 of the human H-ras proto-oncogene. Nucleic Acids Res. 1994; 22:2519-2524. [PubMed: 8041613]

39. Bassett E, Vaisman A, Havener JM, Masutani C, Hanaoka F, Chaney SG. Efficiency of extension of mismatched primer termini across from cisplatin and oxaliplatin adducts by human DNA polymerases $\beta$ and $\eta$ in vitro. Biochemistry. 2003; 42:14197-14206. [PubMed: 14640687]

40. Gruschus JM, Ferretti JA. ${ }^{15} \mathrm{~N}$-edited three-dimensional NOESY-HMQC with water flipback: Enhancement of weak labile ${ }^{1} \mathrm{H}$ resonances of protein side chains contacting DNA. J Magn Reson. 1998; 135:87-92. [PubMed: 9799680]

41. Wuthrich, K. NMR of proteins and nucleic acids. Wiley; New York: 1986.

42. Sklenar V, Miyashiro H, Zon G, Miles HT, Bax A. Assignment of the ${ }^{31} \mathrm{P}$ and ${ }^{1} \mathrm{H}$ resonances in oligonucleotides by two-dimensional NMR spectroscopy. FEBS Lett. 1986; 208:94-98. [PubMed: 3770213]

43. Brunger AT, Adams PD, Clore GM, DeLano WL, Gros P, Grosse-Kunstleve RW, Jiang JS, Kuszewski J, Nilges M, Pannu NS, Read RJ, Rice LM, Simonson T, Warren GL. Crystallography \& NMR system: A new software suite for macromolecular structure determination. Acta Crystallogr. 1998; D54(Part 5):905-921.

44. Yao S, Plastaras JP, Marzilli LG. A molecular mechanics AMBER-type force field for modeling platinum complexes of guanine derivatives. Inorg Chem. 1994; 33:6061-6077. 
45. Kuszewski J, Schwieters C, Clore GM. Improving the accuracy of NMR structures of DNA by means of a database potential of mean force describing base-base positional interactions. $\mathrm{J}$ Am Chem Soc. 2001; 123:3903-3918. [PubMed: 11457140]

46. Eastman A. Reevaluation of the interactions of cisdiamminedichloro(ethylenediamine)platinum(II) with DNA. Biochemistry. 1986; 25:3912-3915. [PubMed: 3741840]

47. Comess KM, Burstyn JN, Essigmann JM, Lippard SJ. Replication Inhibition and Translesion Synthesis on Templates Containing Site-Specifically Placed cis-Diamminedichloroplatinum(II) DNA Adducts. Biochemistry. 1992; 31:3975-3990. [PubMed: 1314653]

48. Bhattacharyya D, Marzilli PA, Marzilli LG. Exploring the universality of unusual conformations of the 17-membered $\left.\mathrm{Pt}\left(\mathrm{dG}^{*} \mathrm{pG}^{*}\right)\right)$ macrochelate ring. Dependence of conformer formation on a change in bidentate carrier ligand from an sp3 to an sp2 nitrogen donor. Inorg Chem. 2005; 44:7644-7651. [PubMed: 16212391]

49. Chen X, McDowell JA, Kierzek R, Krugh TR, Turner DH. Nuclear magnetic resonance spectroscopy and molecular modeling reveal that different hydrogen bonding patterns are possible for GU pairs: One hydrogen bond for each G•U pair in r(GGCGUGCC) 2 and two for each $\mathrm{G} \bullet \mathrm{U}$ pair in r(GAGUGCUC) $)_{2}$. Biochemistry. 2000; 39:8970-8982. [PubMed: 10913310]

50. Cohen SM, Mikata Y, He Q, Lippard SJ. HMG-Domain protein recognition of cisplatin 1,2intrastrand $\mathrm{d}(\mathrm{GpG})$ cross-links in purine-rich sequence contexts. Biochemistry. 2000; 39:1177111776. [PubMed: 10995245]

51. Dunham SU, Lippard SJ. DNA sequence context and protein composition modulate HMG-domain protein recognition of ciplatin-modified DNA. Biochemistry. 1997; 36:11428-11436. [PubMed: 9298962] 


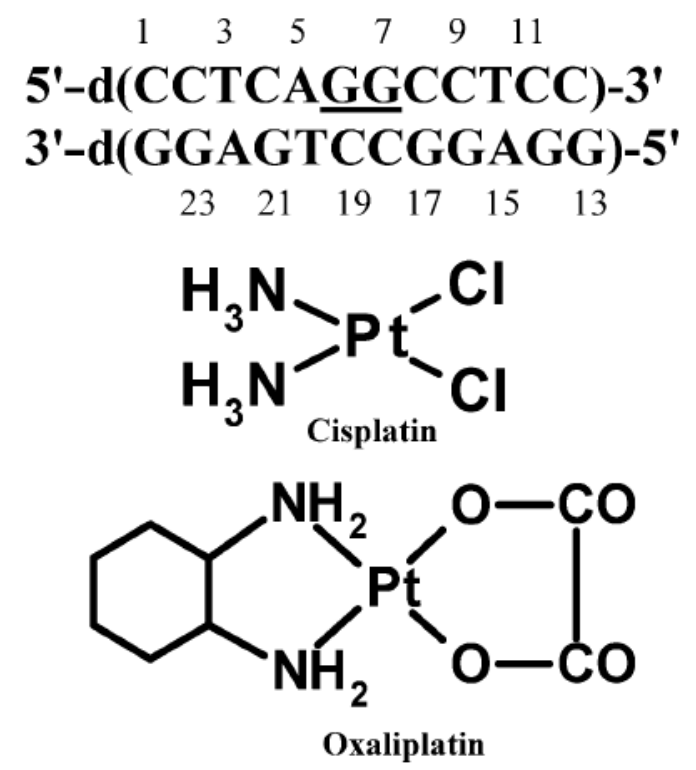

FIGURE 1.

Duplex DNA sequence used in this study. The underlined bases show the position of the platinum adduct. Chemical structures of cisplatin and oxaliplatin. 

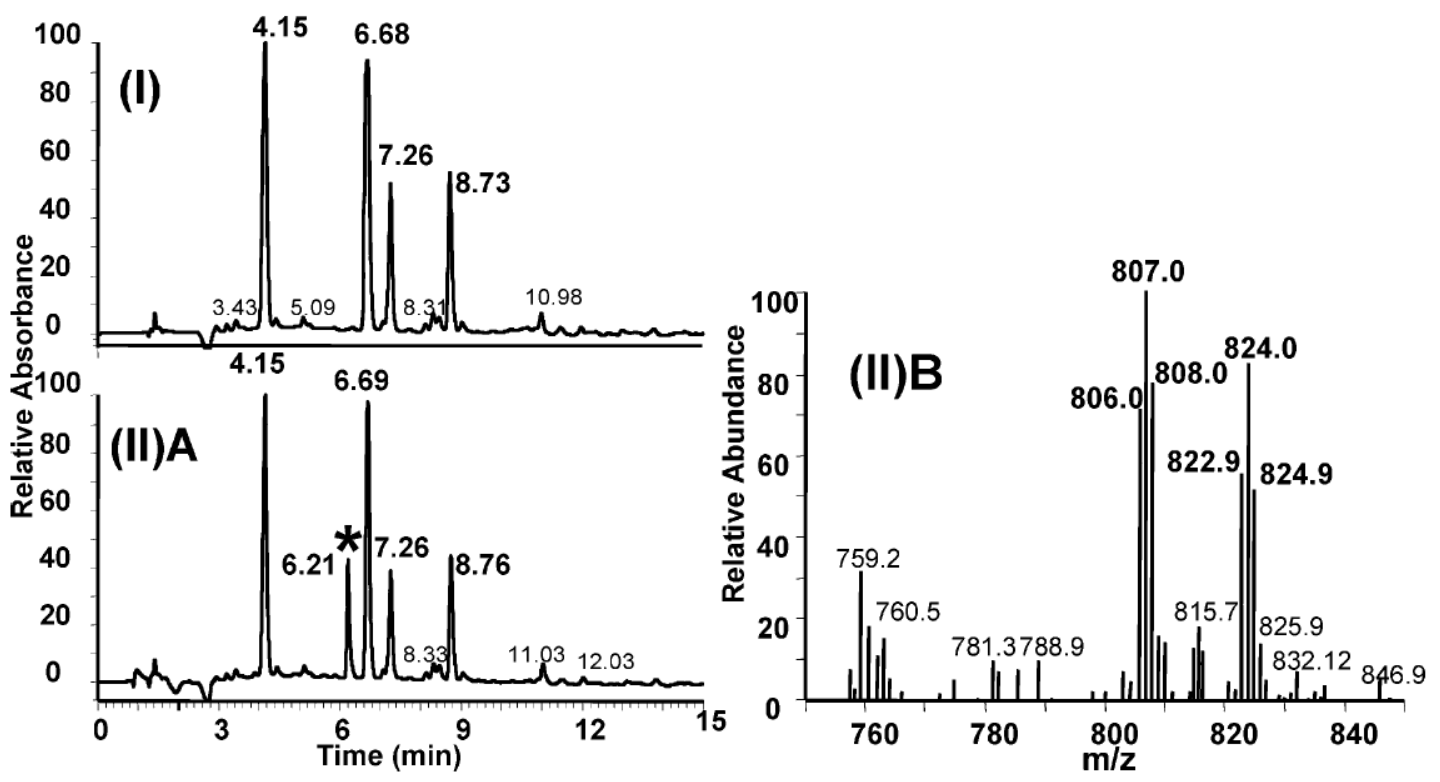

FIGURE 2.

HPLC-UV-MS chromatogram of digestion products obtained from an undamaged 12-mer duplex (I) and from the same 12-mer duplex containing the CP-GG intrastrand cross-link. The spectra include (I) the HPLC-UV elution profile of the digestion products obtained from the undamaged 12-mer duplex, (II)A the HPLC-UV elution profile of the digestion products obtained from the 12-mer duplex containing the $\mathrm{CP}-\mathrm{GG}$ adduct [the peak with the asterisk corresponds to the elution position of a $\mathrm{CP}-\mathrm{d}(\mathrm{GpG})$ standard], and (II)B MSpositive mass spectrum of the peak identified with the asterisk in Figure 2(II)A. 


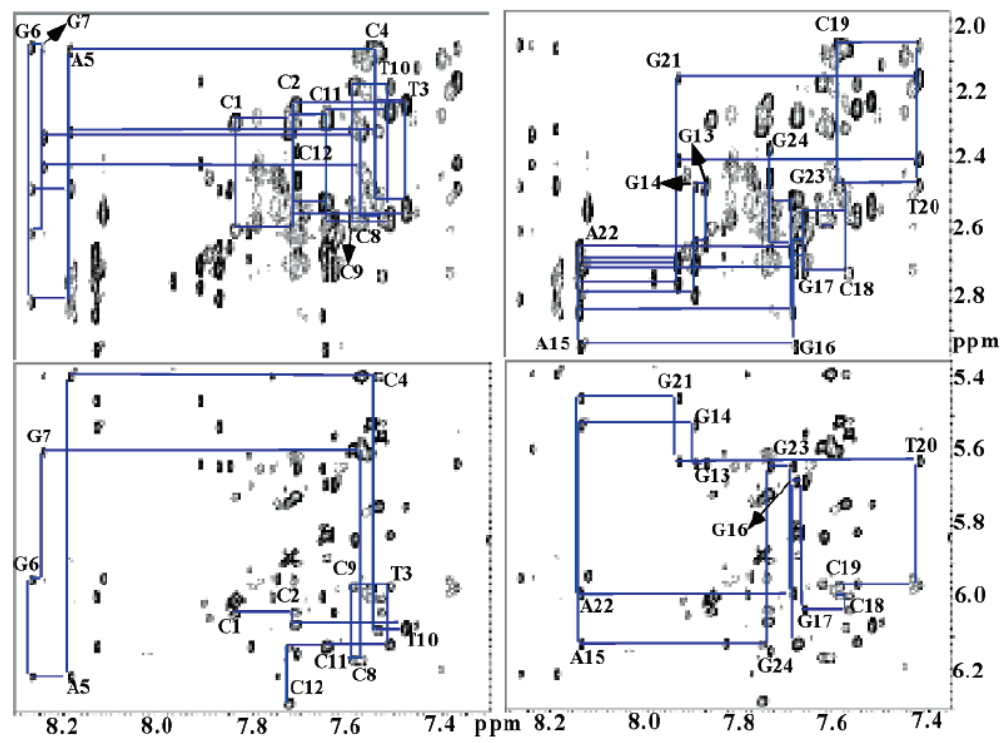

FIGURE 3.

Expanded nonexchangeable proton regions taken from the 2D NOESY $(200 \mathrm{~ms})$ spectrum acquired in $\mathrm{D}_{2} \mathrm{O}$ for the CP-GG 12-mer duplex. The H6/H8-H2'/H2" (top) and H6/H8$\mathrm{H} 1^{\prime}$ (bottom) regions are shown. The left and right regions correspond to the GG (the strand containing the Pt-GG adduct) and CC (complementary) strands, respectively. 

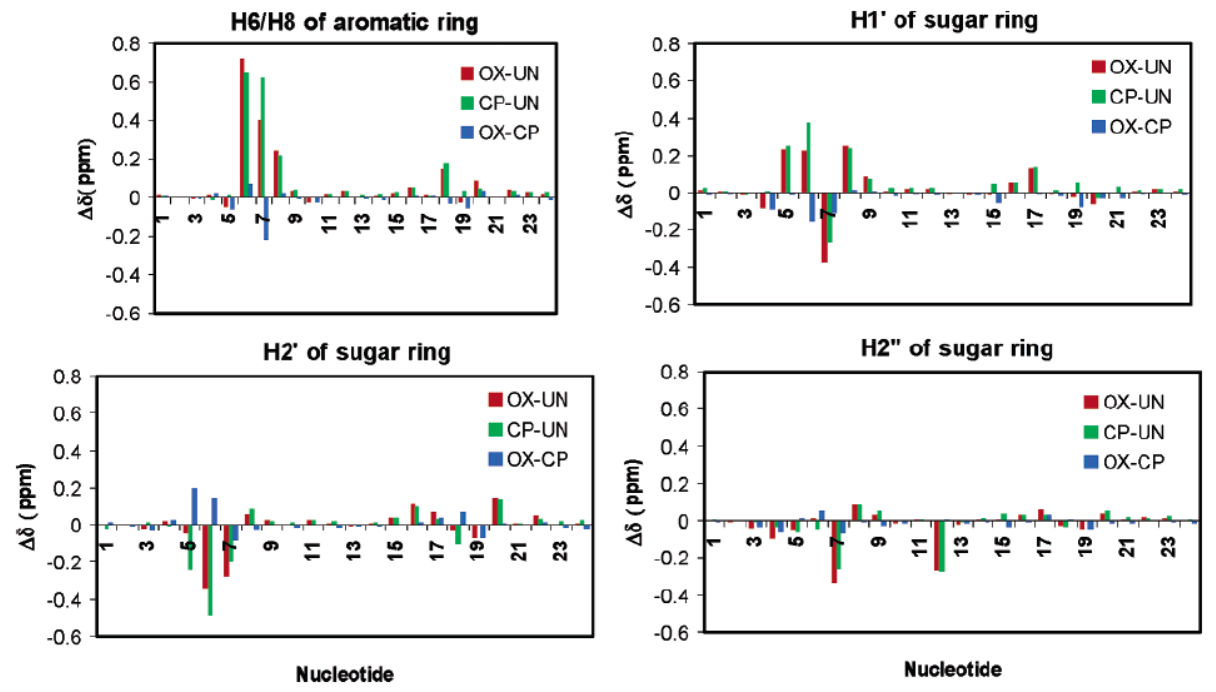

FIGURE 4.

Effect of platination on chemical shifts of selected base and sugar proton chemical shifts. The values were determined by using experimental chemical shifts (Tables S1 and S2 and ref 26). 

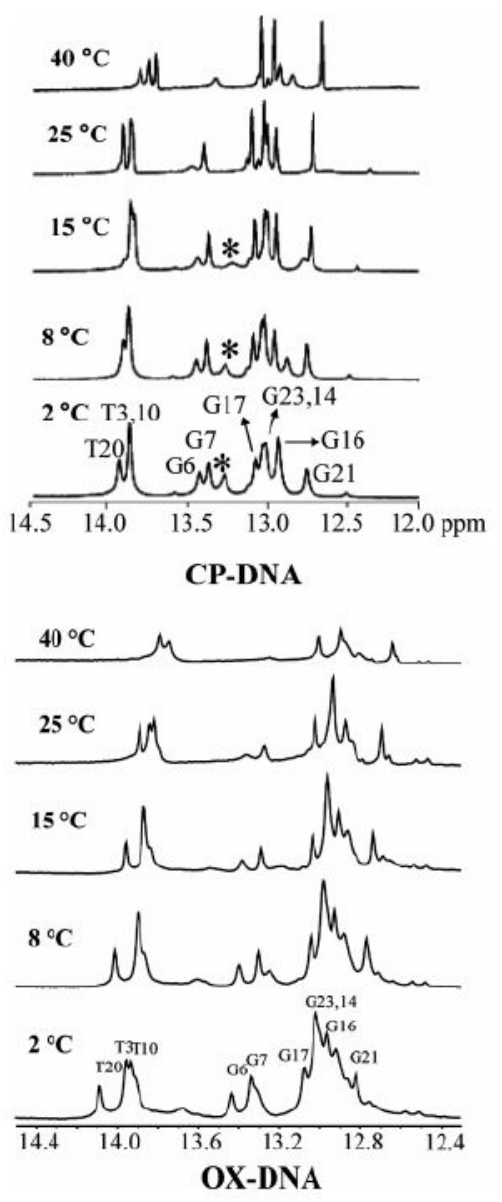

FIGURE 5.

Expanded imino region from $1 \mathrm{D}{ }^{1} \mathrm{H}$ NMR spectra of the CP-DNA (top) and OX-DNA (bottom) (26) duplexes recorded in $\mathrm{H}_{2} \mathrm{O}$ buffer at various temperatures. The positions of the nucleotides in the 12-mer duplexes that give rise to the resonances are indicated. The asterisk in the $1 \mathrm{D}{ }^{1} \mathrm{H}$ NMR spectra of the $\mathrm{CP}-\mathrm{DNA}$ adduct indicates the terminal guanine (G24). The experimental temperatures are shown at the left. 

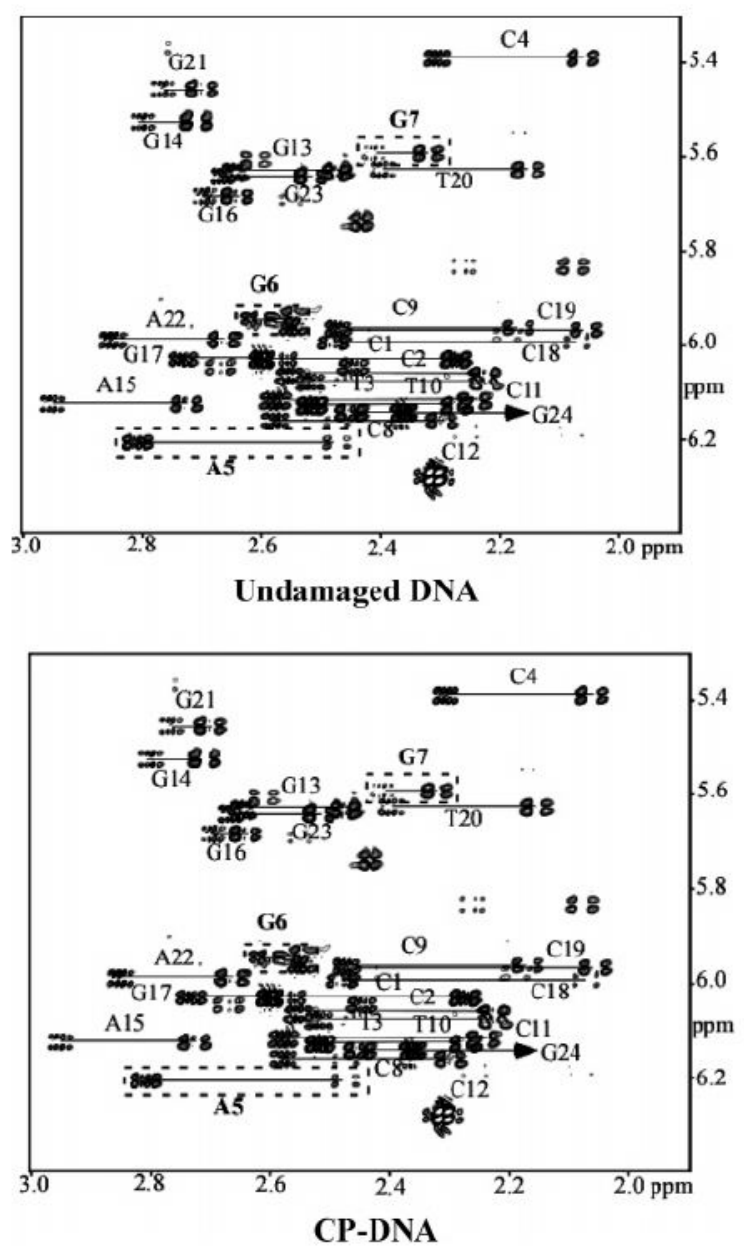

FIGURE 6.

Expanded region of the DQF-COSY spectra showing the $\mathrm{H} 1^{\prime}-\mathrm{H} 2^{\prime}$ and $\mathrm{H} 1^{\prime}-\mathrm{H} 2^{\prime \prime}$ crosspeaks of the undamaged DNA and CP-DNA duplex at $25^{\circ} \mathrm{C}$ in $\mathrm{H}_{2} \mathrm{O}$. Assigned peaks are labeled. 

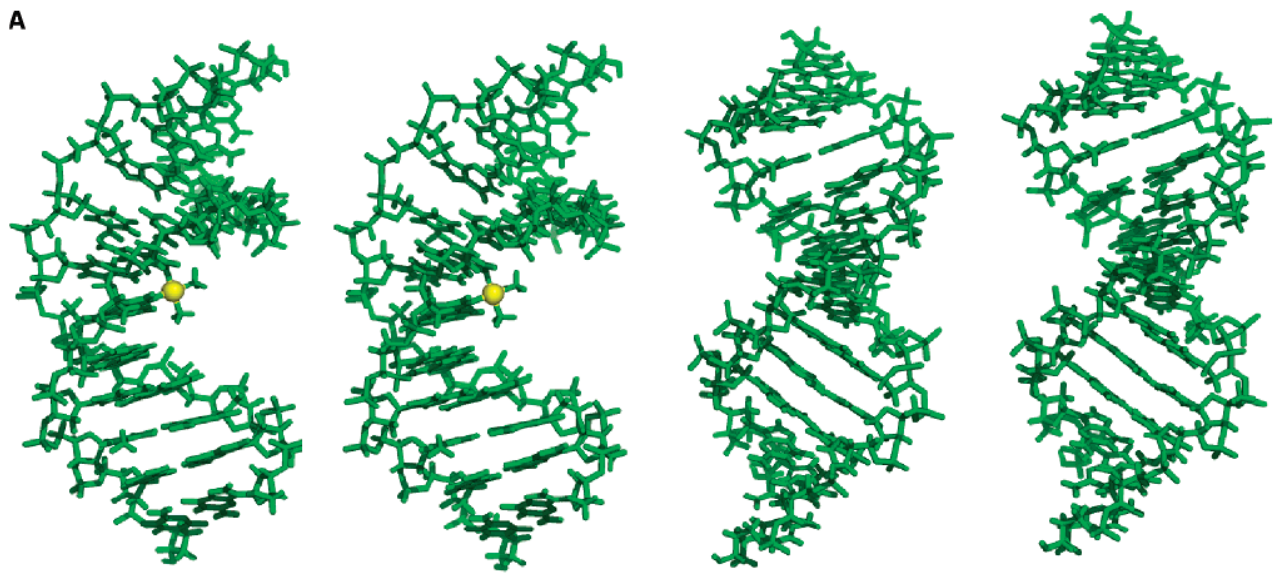

\section{CP-DNA}

B
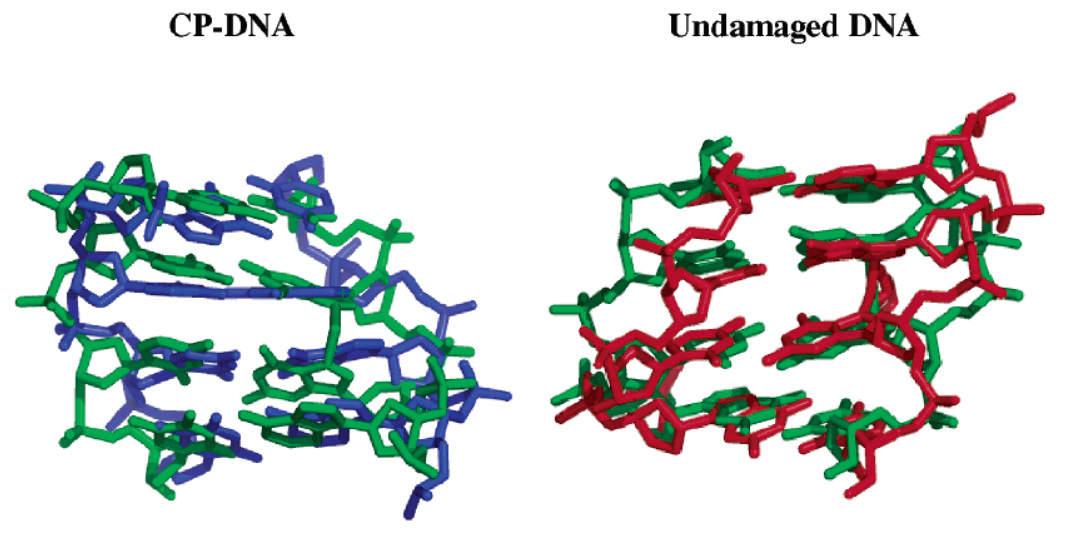

FIGURE 7.

(A) Stereoviews of the average solution structures of the CP-DNA duplex (left) and undamaged DNA (right) in the AGGC sequence context. The platinum atom in the $\mathrm{CP}-$ DNA adduct is shown as a yellow sphere. (B) Comparison of the central $4 \mathrm{bp}$ of the $\mathrm{CP}-$ DNA adduct (green) with those of the undamaged DNA (blue) and OX-DNA adduct (red) (26). 
Table 1

Percent South Conformation $\left(f_{\mathrm{S}}\right)$ Derived from Quantitative Simulation of DQF-COSY Data Obtained for Undamaged DNA and CP-DNA and OX-DNA Adducts in the AGGC Sequence Context

\begin{tabular}{|c|c|c|c|}
\hline residue & undamaged & CP-DNA & OX-DNA \\
\hline $\mathrm{C} 1$ & 0.86 & 0.93 & \\
\hline $\mathrm{C} 2$ & 0.93 & 0.89 & 0.91 \\
\hline $\mathrm{T} 3$ & 0.97 & 0.92 & 0.98 \\
\hline $\mathrm{C} 4$ & 0.88 & 0.86 & 0.93 \\
\hline A5 & 0.85 & 0.62 & 0.72 \\
\hline G6 & 0.83 & 0.63 & 0.32 \\
\hline G7 & 0.86 & 0.95 & 0.88 \\
\hline $\mathrm{C} 8$ & & 0.66 & 0.71 \\
\hline $\mathrm{C} 9$ & 0.95 & 0.73 & 0.63 \\
\hline $\mathrm{T} 10$ & 0.83 & 0.80 & 0.98 \\
\hline C11 & 0.92 & 0.92 & \\
\hline \multicolumn{4}{|l|}{$\mathrm{C} 12$} \\
\hline G13 & & 0.81 & \\
\hline G14 & 0.83 & 0.81 & 0.93 \\
\hline A15 & 0.90 & 0.83 & 0.88 \\
\hline G16 & & 0.95 & 0.86 \\
\hline G17 & 0.95 & 0.95 & 0.88 \\
\hline $\mathrm{C} 18$ & 0.93 & 0.80 & 0.73 \\
\hline C19 & 0.85 & 0.80 & 0.71 \\
\hline $\mathrm{T} 20$ & 0.95 & 0.80 & 0.88 \\
\hline G21 & 0.78 & 0.95 & 0.90 \\
\hline A22 & 0.86 & 0.88 & 0.84 \\
\hline \multicolumn{4}{|l|}{$\mathrm{G} 23$} \\
\hline G24 & 0.97 & & \\
\hline
\end{tabular}

Biochemistry. Author manuscript; available in PMC 2008 June 05. 
Table 2

Structural Statistics for CP-DNA and Undamaged DNA Structures ${ }^{a}$

\begin{tabular}{|c|c|c|}
\hline structure-related information & CP-DNA & undamaged DNA \\
\hline \multicolumn{3}{|c|}{ Number of Experimental Distance Constraints } \\
\hline intraresidue & 367 & 531 \\
\hline inter-residue & 144 & 324 \\
\hline cross-strand & 40 & 65 \\
\hline total & 551 & 920 \\
\hline \multicolumn{3}{|c|}{ Number of Empirical Constraints } \\
\hline hydrogen bonds & 72 & 72 \\
\hline backbone dihedral angles & 168 & 168 \\
\hline \multicolumn{3}{|c|}{ Structural Statistics } \\
\hline distance violation per structure $(>0.5 \AA)$ & 0 & 1 \\
\hline dihedral angle violations per structure $\left(>5^{\circ}\right)$ & 0 & 0 \\
\hline \multicolumn{3}{|l|}{ rmsd from ideal covalent geometry } \\
\hline bond lengths $(\AA)$ & $0.01 \pm 0.00$ & $0.01 \pm 0.01$ \\
\hline bond angles (deg) & $0.66 \pm 0.03$ & $0.78 \pm 0.03$ \\
\hline dihedral angles (deg) & $0.00 \pm 0.00$ & $0.00 \pm 0.00$ \\
\hline \multicolumn{3}{|c|}{ Structure Quantity } \\
\hline \multirow{2}{*}{\multicolumn{3}{|c|}{$\begin{array}{l}\text { rmsd from the mean structure } \\
\text { within the family }(\AA)\end{array}$}} \\
\hline & & \\
\hline all atoms & $0.92 \pm 0.30$ & $1.37 \pm 0.30$ \\
\hline non-H atoms & $0.81 \pm 0.26$ & $1.21 \pm 0.30$ \\
\hline
\end{tabular}

${ }^{a}$ Of 20 calculated structures, the 15 with the lowest energy are accepted as a family. 
Table 3

Comparison of Selected 3-DNA and MADBEND Parameters for Undamaged DNA, CP-GG DNA, OX-GG DNA (26), and DNA from the HMG-CP-GG DNA Complex (31)

\begin{tabular}{|c|c|c|c|c|}
\hline & undamaged & CP-DNA & OX-DNA & HMG-CP-DNA \\
\hline \multicolumn{5}{|l|}{$\mathrm{A} 5 \cdot \mathrm{T} 20 / \mathrm{G} 6 \cdot \mathrm{C} 19$} \\
\hline $\operatorname{shift}(\AA)$ & $0.44 \pm 0.05$ & $-0.04 \pm 0.10$ & $0.17 \pm 0.04$ & 1.17 \\
\hline slide $(\AA)$ & $0.09 \pm 0.08$ & $-0.65 \pm 0.10$ & $-0.89 \pm 0.10$ & 1.32 \\
\hline twist (deg) & $27.81 \pm 0.58$ & $35.3 \pm 1.40$ & $22.1 \pm 1.30$ & 31.7 \\
\hline \multicolumn{5}{|l|}{$\mathrm{G} 6 \cdot \mathrm{C} 19 / \mathrm{G} 7 \cdot \mathrm{C} 18$} \\
\hline $\operatorname{shift}(\AA)$ & $0.24 \pm 0.05$ & $0.99 \pm 0.08$ & $0.84 \pm 0.14$ & -0.78 \\
\hline slide $(\AA)$ & $-1.55 \pm 0.08$ & $-0.55 \pm 0.10$ & $-1.36 \pm 0.30$ & -1.66 \\
\hline twist (deg) & $30.29 \pm 0.58$ & $18.40 \pm 1.40$ & $25.20 \pm 2.00$ & 19.20 \\
\hline roll (deg) & $1.12 \pm 0.74$ & $36.30 \pm 3.20$ & $28.30 \pm 3.20$ & 57.20 \\
\hline \multicolumn{5}{|l|}{$\mathrm{G} 7 \cdot \mathrm{C} 18 / \mathrm{C} 8 \cdot \mathrm{G} 17$} \\
\hline $\operatorname{shift}(\AA)$ & $0.24 \pm 0.05$ & $-0.99 \pm 0.17$ & $-1.24 \pm 0.1$ & -0.45 \\
\hline slide $(\AA)$ & $-1.55 \pm 0.08$ & $-0.33 \pm 0.13$ & $0.93 \pm 0.10$ & 0.08 \\
\hline \multicolumn{5}{|l|}{$\mathrm{G} 6 \cdot \mathrm{C} 19$} \\
\hline buckle (deg) & $10.39 \pm 0.31$ & $4.20 \pm 2.20$ & $12.60 \pm 2.40$ & 29.00 \\
\hline \multicolumn{5}{|l|}{$\mathrm{G} 7 \cdot \mathrm{C} 18$} \\
\hline buckle (deg) & $-0.90 \pm 0.31$ & $-4.58 \pm 1.67$ & $-3.18 \pm 1.70$ & -11.80 \\
\hline opening (deg) & $0.83 \pm 0.24$ & $-1.24 \pm 0.93$ & $5.73 \pm 0.53$ & -5.20 \\
\hline G6G7 dihedral angle & & $42.70 \pm 3.10$ & $35.60 \pm 2.80$ & \\
\hline overall bend (deg) (MADBEND) & & $22 \pm 10$ & $31 \pm 10$ & \\
\hline
\end{tabular}

